\title{
THE IDEA OF REGULATING OF GOVERNOR'S AUTHORITY AS GOVERNMENT'S REPRESENTATIVE POST THE AMENDMENT OF 1945 CONSTITUTION (GAGASAN PENGATURAN KEWENANGAN GUBERNUR SEBAGAI WAKIL PEMERINTAH SETELAH PERUBAHAN UNDANG UNDANG DASAR 1945)
}

\author{
Yuslim, Fak. Hukum Unand, Padang, email. yuslim_1957@yahoo.com.
}

\begin{abstract}
The idea of regulating of governor's authority as representative of central government to the regency/town government after the amendment of 1945 constitution is aimed at answering two legal problems. They are: (1) How is the regulation of the authority of governor as representative of central government after the amendment of 1945 constitution, (2) How is the idea governor as the representative of government. In order to answer such a questions the research conducted by using legal/normative research. The approach that used is statue approach and conceptual approach.

The regulating of governor's authority as representative of central government as stipulated in Art. 32 of Act No.32 year of 2004 do not have firm validity in 1945 Constitution. Such the authority of governor is conducted as the implementation of principle of de-concentration, while such a principle does not clearly formulated in 1945 constitution. Besides it does not have constitution's validity, the regulating of governor's authority in Act No.32, 2004 does not have clear concept since on one hand such authority is attribution, an on one hand that authority is a delegation and even in practice it is a mandate.

According of Unitary state's point of view the authority of governor as direct representative of central government after the amendment of 1945 constitution should be in delegation form. Therefore it is not directly enumerated in Act regarding the Local government (attribution). The president that would transfer that authority in government regulation (pp). The delegation of authority to the governor should cover the affair of general government in province, so it is not just limited to a certain affair.Besides in conducting the authority, the governor as representative of central government needs certain organ that assist the governor in performing his authority and as the organ of central government.
\end{abstract}

Key word: The idea, governor's authority, government's representat, unitary state.

\begin{abstract}
Abstrak
Gagasan penaturan kewenangan gubernur sebagai wakil pemerintah terhadap kabupaten/ kota setelah perubahan Undang-Undang Dasar 1945 bertujuan menjawab 2(dua) problem hukum, yakni : (1) Bagaimana pengaturan kewenangan gubernur sebagai wakil pemerintah setelah perubahan UUD 1945, dan (2) Bagaimana gagasan kewenangan gubernur sebagai wakil pemerintah. Untuk menemukan jawaban pertanyaan yang muncul dilakukan penelitian hukum normatif dengan pendekatan perundang-undangan (statute approach) dan pendekatan konseptual (conceptual approach).

Pengaturan kewenangan gubernur sebagai wakil pemerintah dalam Pasal 38 UU No. 32/2004 tidak memiliki validasi yang tegas dalam UUD 1945.Kewenangan gubernur tersebut dilakukan dalam rangka pelaksanaan asas dekonsentrasi, sementara asas dekonsentrasi tidak dirumuskan secara tegas dalam UUD 1945.Selain tidak memiliki validasi konsitusi, pengaturan kewenangan gubernur dalam UU No. 32/2004 tidak jelas konsepnya karena satu sisi kewenangan tersebut berupa atribusi, pada bagian lain berupa delegasi dan bahkan dalam praktek berupa mandat.

Menurut sudut pandang sistem negara kesatuan (unitary state) kewenangan gubernur sebagai wakil pemerintah langsung setelah perubahan UUD 1945 haruslah berupa delegasi kewenangan.Jadi tidak ditegaskan (dirinci) langsung dalam UU mengenai pemerintahan daerah (atribusi). Presiden yang akan melimpahkan kewenangan tersebut nantinya dalam Peraturan Pemerintah. Pelimpahan kewenangan kepada gubernur tersebut ruanglingkupnya haruslah mencakup urusan pemerintahan umum di provinsi jadi tidak dibatasi pada urusan tertentu saja.Selain itu dalam menjalankan kewenangan gubernur sebagai wakil pemerintah perlu organ tertentu yang membatu gubernur dalam menjalankan kewenangannya dan merupakan organ pemerintah.
\end{abstract}

Key word: Gagasan, Kewenangan Gubernur, Wakil Pemerintah, Negara Kesatuan. 


\section{A. PENdAHULUAN}

\section{Latar Belakang}

Dalam sistem pemerintahan daerah di Indonesia kedudukan gubernur cukup strategis karena selain berkedudukan sebagai kepala daerah, gubernur juga merupakan wakil pemerintah (pusat) di wilayahnya.Kedudukan gubernur sebagai wakil pemerintah merupakan perwujudan penyelenggaraan urusan pemerintah pusat melalui asas dekonsentrasi. Tetapi sejak era baru dalam otonomi dengan menguatnya otonomi kabupaten/kota kewenangan gubernur sebagai wakil pemerintah terhadap kabupaten/kota tidak berjalan sebagai mana mestinya.Prilaku bupati/walikota semakin menunjukan keengganan untuk berkoordinasi dengan pemerintah pusat (Djohermansah Djohan, 2010).Sehingga pembinaan, pengawasan dan koordinasi yang merupakan kewenangan gubernur tidak efektif.

Dilihat dari teori kewenangan suatu organ pemerintah dapat memperoleh kewenangan melalaui atribusi, delegasi atau mandate (van Wijk/Konijnenbelt, 1991: 56-65). Sehubungan dengan kewenangan gubernur sebagai wakil pemerintah yang diatur oleh UndangUndang Nomor 32 tahun 2004 tentang Pemerintahan Daerah (UU No.32/2004), belum memiliki konsep kewenangan yang jelas karena satu sisi Pasal 10 UU No. 32/2004 kewenangan gubernur berupa delegasi, Karena kewenangan gubernur bersumber dari penyerahan wewenang yang dimiliki presiden (Agussalim, 2007:104). Sedangkan kewenangan gubernur sebagai wakil pemerintah berdasarkan pasal 38 ayat (1) berupa atribusi karena kewenangan tersebut langsung diberikan oleh pembentuk UU (S.F Marbun, 2003:123, Indroharto,1990: 65.Selanjutnya menurut PP No. 79 tahun 2007 tentang Pembinaan dan Penyelenggaraan Pemerintahan Daerah (PP No.79/2005) gubernur hanya menjalankan kewenangan yang tugaskan oleh presiden melalui menteri dan dari menteri kepada gubernur artinya tidak terjadi perpindahan wewenang sehingga kewenangan tersebut dikategorikan mandat (Agussalim:106;S.F.Marbun:128). Dengan tidak jelasnya bentuk kewenangan gubernur sebagai wakil pemerintah dengan sendirinya gubernur tidak dapat melakukan tindakan terhadap bupati/walikota sehingga akan berdampak pada wibawa gubernur dimata bupati/walikota.
Selain belum jelasnya konsep kewenangan gubernur sebagai wakil pemerintah, ruang lingkup kewenangan gubernur tersebut juga dipertanyakan secara akademis karena hanya mengatur sebagian kecil dari kewenangan tugas dekonsentrasi. Pada hal kedudukan gubernur sebagai wakil pemerintah dalam rangka menjalankan tugas dan wewenangnya menurut asas dekonsentrasi. Problematik kewenangan gubernur semakin parah ketika dikaji organ yang melaksanakan kewenangan tersebut, karena ketiadaan pengaturan mengenai organ yang membantu gubernur sebagai wakil pemerintah menjalankan tugas dan wewenangnya, dalam prakteknya hal itu dilakukan oleh Satuan Kerja Perangkat Daerah (SKPD).Keadaan tersebut secara konsepsional tidak tepat karena kewenangan pemerintah dilakukan oleh organ daerah.

Menghadapi kenyataan tersebut pemerintah mengeluarkan kebijakan untuk memperkuat posisi gubernur dengan menetapkan Peraturan Pemerintah Nomor 19 tahun 2010 tentang Tata Cara Pelaksanaan Tugas dan Wewenang serta Kedudukan Keuangan Gubernur sebagai Wakil Pemerintah di Wilayah Provinsi (PP No.19/2010) sebagaimana diubah dengan PP No. 23/2011. Meskipun telah diundangkan PP No. 19/2010 diubah dengan PP No.23/2011 mengenai kewenangan gubernur sebagai wakil pemerintah masih menimbulkan persoalan hukum, sehingga perlu dicarikan gagasan yang pas sesuai dengan bentuk negara Indonesia.

\section{Metoda Penelitian}

Metoda yang digunakan dalam penelitian ini penelitian hukum normatif. Menurut $F$. Sugeng Istanto, penelitian hukum adalah penelitian yang diterapkan atau diperlakukan khusus pada ilmu hukum (F. Sugeng Istanto, 2007:29). Menurut pandangan Jan Gijssels dan Mark van Hoecker penelitian hukum adalah suatu proses untuk menemukan aturan hukum, prinsip-prinsip hukum maupun dokrin-dokrin hukum untuk menjawab isue hukum yang dihadapipenelitian hukum adalah suatu proses untuk menemukan aturan hukum, prinsip-prinsip hukum maupun dokrin-dokrin hukum untuk menjawab isue hukum yang dihadapi (Peter Mahmud Marzuki, 2007:29). Dalam penelitian ini, digunakan pendekatan statute approach 
maupun conceptual approach. Menurut L.Cohen terdapat beberapa pendekatan dalam penelitian hokum yakni statute approach, conceptual approach analitycal approach, comparative approach, hystorical approach, philosophical approach, dan case approach(Saldi Isra, 2009: 13). Sedangkan sumber data adalah data sekunder, berupa bahan hukum baik bahan hukum primer, sekunder maupun tersier.Analisis bahan hukum dilakukan melalui kontein analisis terhadap bahan hukum yang tersedia.

\section{Kerangka Teoritis}

Setiap jabatan atau organ pemerintah kewenangan adalah sesuatu yang prinsipil sebagai justifikasi untuk dapat melakukan perbuatan hukum.dari. Kewenangan selalu berkaitan dengan kekuasaan yang diperoleh secara hukum oleh pejabat atau organ pemerintah, karena itu tidak lepas dari teori negara hukum (the rule of law). Salah satu unsur penting dari negara hukum adalah terdapatnya asas legalitas, asas mana diwujudkan dalam wet matigheid van bestuur(Philipus M.Hajon, 1993). Asas legalitas mengandung makna bahwa tanpa adanya dasar wewenang yang diberikan oleh suatu peraturan perundang-undangan yang berlaku, maka segala tindakan aparat pemerintah tidakdapat mempengaruhi keadaan atau posisi hukum warga masyarakat (Indroharto:58).

Makna dari asas legalitas adalahsetiap tindakan pejabat atau badan tata usaha negara harus berdasarkan atas UU formal atau hukum baik tertulis maupun tidak tertulis (Agussalim:98).Dalam bahasa Prancis asas tersebut dinamakan le principede la le'galite' de l'administration; di Jerman dinamakan gesetzmassigkeit derVerwaltung. Di Inggris asas tersebut dianggap sebagai bagian dari the rule of law (Indroharto, I, 2004, 830.

Sehubungan dengan makna kewenangan Saldi Isra mengutip pandangan Marbun mengatakan, kewenangan adalah kekuasaan yang diformalkan baik terhadap golongan orang tertentu maupun terhadap bidang tertentu pemerintahan (Saldi Isra, 2010;11). Pandangan lain mengatakan wewenang yang mengandung makna kekuasaan (macht) ada pada organ (organ), sedangkan tugas (taak) dan hak (recht), ada pada pejabat atau organ ambtdrager, (Bagir Manan: 69). Berdasarkan pandangan ahli di atas dapat disimpulkan bahwa kewenangan adalah kekuasaan yang diberikan kepada organ pemerintahan sebagai dasar justifikasi bagi organ tersebut untuk melakukan suatu tindakan hukum yang ditujukan kepada seseorang atau suatu badan hukum.

Dalam doktrin kewenangan ditegaskan sumber kewenangan suatu organ atau jabatan diperoleh melalui cara sebagai atribusi, delegasi dan mandat (van Wijk/Konijnenbelt, 1991; Ridwan AR, 2006: 100). Menurut van Wijk-Konijnenbelt atribusi adalah" toekenning van een bestuurs bevoegdheid toekenning door een wetgever, aan een bestuurorgan". Atribusi, adalah pemberian wewenang pemerintahan oleh pembuat undang-undang kepada organ pemerintah).Jadi, kewenangan atribusi merupakan kewenangan yang diberikan langsung oleh UU atau diberikan oleh legislator utama (primary legislator). Dengan demikian kewenangan atribusi merupakan wewenang yang melekat pada suatu jabatan/organ (Philipus M. Hadjon, et all, 1993,:130).

Kewenangan berbentuk delegasi (delegatie) mengandung arti penyerahan wewenang dari pejabat yang lebih tinggi kepada pejabat yang lebih rendah (Agussalim:104).Menurut Indrohartopada delegasi terjadi pelimpahan suatu wewenang yang telah ada oleh badan atau Pejabat TUN yang telah memperoleh wewenang pemerintahan secara atribusi kepada Badan atau Pejabat TUN lainnya (Indroharto:65). Jadi pada setiap delegasi harus didahului oleh suatu kewenangan atribusi. Pandangan yang sama juga dikemukakan oleh Hadjon yang mengatakan kita berbicara tentang delegasi dalam hal ada pelimpahan/penyerahan suatu kewenangan yang ada.Hakekat hukum dari delegasi adalah terjadinya perpindahan kewenangan dan kegaligus perpindahan pertanggung jawaban/pertanggung gugatan. Dengan demikian penerima delegasi bertinda untuk dan atas nama jabatannya.

Kewenangan berbentuk mandat (mandaat) mengandung pengertian perintah (opdracht) yang di dalam hubungan hukum berupa baik pemberi kuasa (lastgeving) maupun kuasa penuh (volmacht).Jimly Asshiddiqie menggunakan istilah pelimpahan wewenang atau transfer of power (Jimly Asshiddiqie,hlm. 264).Pada mandat tidak ada penciptaan ataupun penyerahan wewenang. Ciri mandatadalah penerima mandat bertindak untuk dan atas nama pemberi mandat sehingga pemberi mandat (mandant) 
tetap berwenang untuk menangani sendiri wewenangnya bila ia menginginkannya (Agussalim:106). Menurut Bothlingkdalam hukum tata negara, mandat dapat diartikan sebagai perintah yang diberikan oleh seorang pejabat atas nama jabatan atau golongan jabatan kepada pihak ketiga untuk melaksanakan sebagian tugas pejabat itu atas nama jabatan atau golongan jabatan (Harun Al Rasid, 1997: 87).

\section{B. Hasil dan Pembahasan}

\section{Kewenangan Gubernur Sebagai Wakil Pemerintah Terhadap Kabupaten/Kota.}

Eksistensi institusi pemerintahan provinsi diatur dalam Pasal 18 UUD 1945 dengan organ pemerintahan terdiri dari gubernur dan DPRD provinsi. Selanjutnya UUD 1945 menegaskan bahwa gubernur berkedudukan sebagai kepala pemerintahan daerah provinsi. Dalam penyelenggaraan pemerintahan gubernur selain berkedudukan sebagai kepala pemerintahan daerah provinsi juga sebagai wakil pemerintah di wilayahnya. UUD 1945 tidak mengatur kedudukan gubernur sebagai wakil pemerintahan, tetapi kedudukan tersebut selalu dikaitkan dengan kekuasaan presiden sebagai kepala pemerintahan.

Kedudukan gubernur sebagai kepala pemerintahan daerah dan sebagai wakil pemerintah di tegaskan dalam Pasal 37 UU No. 32/2004 yang menegaskan gubernur yang karena jabatannnya berkedudukan juga sebagai wakil pemerintah di wilayah provinsi yang bersangkutan.Dengan adanya ketentuan tersebut berarti dalam diri seorang gubernur terdapat dua fungsi sekaligus atau dikatakan kedudukan gubernur bersifat dualistis.Dalam kedudukannya yang dualistis tersebut di mana gubernur selain merupakan organ pemerintahan provinsi juga sebagai wakil pemerintah, yakni perpanjangan tangan perintahan di provinsi.Terdapatnya pengaturan kedudukan gubernur sebagai wakil pemerintah dalam hubungannya dengan UUD 1945 menimbulkan pertanyaan mengenai validitas ketentuan tersebut apakah dapat dicarikan dasar belakunya dalam UUD 1945 tersebut.

UUD 1945 sebagai hukum dasar merupakan hukum tertinggi di negara (supreme law of the land) di Indonesia.Di dalam UUD 1945 di atur tatanan dasar kehidupan bernegara seperti bentuk negara, bentuk pemerintahan, kelembagaan negara, hak asasi manusia dan lain-lain.Di antara ketentuan dasar yang diatur adalah penyelenggaraan pemerintahan daerah. Dalam Pasal 18 ayat (2) UUD/1945 ditegaskan "Pemerintahan daerah provinsi, daerah kabupaten dan kota mengatur dan mengurus sendiri urusan pemerintahan menurut asas otonomi dan tugas pembantuan". Untuk melaksanakan asas otonomi dan tugas pembantuan pada setiap provinsi diperlukan eksistensi gubernur sebagai kepala pemerintahan provinsi.

Sehubungan dengan Pasal 18 ayat (2) UUD 1945 tersebut di atas, di daerah (provinsi) hanya dikenal dua asas pemerintahan yakni asas otonomi dan tugas pembantuan. Sedangkan dalam doktrin lazimnya dikenal 3 (tiga) asas penyelenggaraan pemerintahan daerah yakni asas dekonsentrasi, asas asas otonom dan asas tugas pembantuan. Dengan hanya disebut 2 (dua) asas pemerintahan daerah dalam UUD 1945 apakah asas dekonsentrasi dapat dilaksanakan (diatur) dalam UU tentang pemerintahan daerah. Pertanyaan tersebut sehubungan dengan kedudukan gubernur sebagai wakil pemerintah, di mana dalam kedudukan tersebut gubernur melaksanakan kewenangan dalam rangka asas dekonsentrasi.Terkait dengan pertanyaan di atas, telah menimbulkan persepsi yang berbeda dikalangan para ahli hukum. Menurut Bagir Manan boleh saja asas dekonsentrasi di jalankan di daerah karena dalam doktrin dikenal tiga asas penyelenggaraan pemerintahan yakni asas otonomi, asas tugas pembantuan dan asas dekonsentrasi (Bagir Manan:174) Sedangkan menurut Jimly Asshiddiqqie diakui asas dekonsentrasi setelah amandemen UUD 1945 seharusnya tidak didasarkan pada doktrin tetapi diatur secara tegas (Jimly Asshiddiqqie, 2002).

Sehubungan dengan pertanyaan boleh tidaknya asas dekonsentrasi dilaksanakan dalam penyelenggaraan pemerintahan daerah setelah perubahan UUD 1945, terhadap hal itu dilakukan kajian dengan pendekatan perundang-undangan. Menurut stufentheorie dari Hans Kelsen maupun Hans Nawiasky di mana menurut teori ini validitas norma hukum ditentukan oleh norma di atasnya (Jimly Asshiddiqie dan Ali Safaat, 2012;100). Jika di cari validitas norma UU No. 32/2004 yang mengatur asas dekonsentrasi menurut strufentheorieyakni 
pada UUD 1945, jelas norma tersebut tidak ditemukan gantungannya dalam UUD 1945. Selanjutnya validitas norma mengenai pengaturan dekonsentrasi dalam UU No. 32/2004 berdasarkan UU No. 12 tahun 2011 tentang Pembentukan Peraturan Perundangundangan harus berdasarkan UUD 1945.

Berdasarkan pembahasan di atas, baik menurut stufenteorie maupun berdasarkan hukum positif yang berlaku pengaturan asas dekonsentrasi dalam UU No. 32/2004 tidak memiliki validitas dalam UUD 1945. Dengan tidak diaturnya asas dekonsentrasi dalam UUD 1945, sementara dasar hukum pengaturan kewenangan gubernur sebagai wakil pemerintah adalah dalam rangka pelaksanaan asas dekonsentrasi, dengan demikian pengaturan kewenangan gubernur sebagai wakil pemerintah dalam Pasal 38 UU No.32/2004 dengan sendirinya juga tidak memiliki validasi dari UUD 1945.

Kondisi tersebut dapat menimbulkan persoalan ketatanegaraan karena secara teori maupun menurut hukum positif, di mana pembuatan norma yang lebih rendah ditentukan oleh norma lain yang lebih tinggi. Karena di dalam UUD 1945 tidak diatur asas dekonsentrasi sedangkan dalam UU No. $32 / 2004$ hal itu di atur, maka kemudian hari ketentuan itu rentan diuji (judicial review) di Mahkamah Konstitusi.Untuk itu, sebaiknya UUD 1945 mengatur dekonsentrasi secara ekplisit. Dengan demikian pengaturan dekonsetrasi dan kewenangan gubernur sebagai wakil pemerintah memiliki validasi dalam konstitusi.

Dalam Pasal 38 UU No. 32/2004 kewenangan gubernur sebagai wakil pemerintah terhadap kabupaten/kota mencakup:

a. melakukan pembinaan dan pengawasan penyelenggaraan pemerintahan daerah kabupaten/kota;

b. koordinasi penyelenggaraan urusan Pemerintah di daerah provinsidan kabupaten/kota;

c. koordinasi pembinaan dan pengawasan penyelenggaraan tugas pembantuan di daerah provinsi dan kabupaten/kota.

Memperhatikan kewenangan gubernur sebagai wakil pemerintah yang diatur dalam Pasal 38 ayat (1) dihubungkan dengan cara seorang pejabat (suatu jabatan) memperoleh, maka kewenangangubernur tersebut berasal langsung dari UU No.32/2004, dengan demikian kewenangan gubernur tersebut bersifat atribusi artinya pembuat UU menciptakan suatu wewenang pemerintahan (yang baru) dan menyerahkannya kepada suatu lembaga pemerintahan (Lukman Hakim, 2012:126). Karena kewenangan gubernur tersebut langsung bersumber dari UU, hal itu berartinya seorang gubernur dalam kedudukannya sebagai wakil pemerintah kewenangannya bersumber dari badan legislator asli (original legislator atau primary legislator).

Kewenangan gubernur dimaksud pasal 38 tersebut jika dihubungkan dengan ketentuan Pasal 10 ayat (5) huruf b UU No. 32/2004 akan membingungkan, karena Pasal 10 ayat (5) huruf b menyatakan “ .... pemerintah dapat melimpahkan sebagian urusan pemerintah kepada gubernur selaku wakil pemerintah". Jika konstruksi pasal 10 ayat (5) huruf b tersebut diikuti, maka kewenangan gubernur sebagai wakil pemerintah berupa delegasi karena wewenang gubernur berasal dari pelimpahan kewenangan (transfer of power) dari presiden. Dengan demikian menurut Pasal 10 ayat (5) huruf b UU No.32/2004, presiden untuk melimpahkan kewenangannya kepada gubernur harus diatur lebih lanjut dalam Peraturan Pemerintah.

Jika Pasal 38 ayat (1) UU No. 32/2004 dihubungkan dengan Pasal 10 ayat 5 huruf $b$, maka pasal 38 ayat (1) bersifat menderogasi pasal 10 ayat 5 huruf $b$, dengan cara memberikan kewenangan atribusi kepada gubernur sebagai wakil pemerintah. Oleh karena itu ketentuan pasal 38 ayat (1) UU No. 32/2004 tidak memerlukan PP yang mengatur kewenangan gubernur sebagai wakil pemerintah. Dengan menggunakan pola fikir Pasal 38 ayat (1) UU No. 32/2004 tersebut perlu dipertanyakan dasar presiden menerbikan PP No. 19 tahun 2010 Tata Cara Pelaksanaan Tugas dan Wewenang Gubernur Sebagai Wakil Pemerintah yang diubah dengan PP No. 23 tahun 2011. Jika dilihat alasan yang melatar belakangi lahirnya kedua PP tersebut di atas hanyalah bersifat psikologis, karena PP tersebut dibentuk untuk memperkuat fungsi gubernur sebagai sebagai wakil pemerintah di wilayah provinsi karena selama ini gubernur kurang dihormati dan dipatuhi oleh bupati/walikota, akibatnya pengawasan dan koordinasi pemerintah tidak berjalan sebagaimana mestinya.

Sehubungan dengan eksistensi PP No. 19/2010 jo PP No.23/2011 tersebut lebih jauh lagi materinya tidak sesuai dengan ketentuan 
Pasal 38 UU No. 32/2004, karena kedua PP tersebut juga mengatururusan polisionil yakni stabilitas politik, ideologi dan demokrasi, etika pemerintahan dan menjaga keutuhan Negara Kesatuan Republik Indonesia (NKRI) yang sebelumnya tidak disebutkan dalam UU. Selain itu, materi kedua PP tersebut materinya bertentangan dengan UU No. 32/2004 tentang organ pelaksana kewenangan gubernur sebagai wakil pemerintah. Di dalam Pasal 17 PP No. 19/2003 di atur "dalam melaksanakan tugas dan wewenang gubernur sebagai wakil pemerintah, gubernur dibantu oleh sekretaris gubernur yang dijabat secara ex officio oleh sekretaris provinsi dan secara operasional dibantu oleh kelompok jabatan fungsional".

Dengan adanya Pasal 17 PP No. 19/2010 tersebut di atas menggambarkan kegamangan atau bahkan kebingungan pemerintah mengenai organ yang akan melaksanakan tugas dan wewenang gubernur sebagai wakil pemerintah. Karena dalam UU No. 32/2004 tidak diatur organ yang akan melaksanakan tugas dan wewenang gubernur tersebut. Hal itu menggambarkan PP No. 19/2010 jo PP No. 23/2011 tidak mendapat validasi dari UU No. 32/2004 bahkan bertentang dengan Pasal 120 ayat (1) UU No. 32/ 2004 karena pasal tersebut dengan tegas mengatakan perangkat daerah provinsi terdiri atas sekretariat daerah, sekretariat DPRD, dinas daerah dan lembaga teknis daerah. Selanjutnya dalam Pasal 121 ayat (1) dinyatakan "Sekretariat daerah dipimpin oleh seorang sekretaris daerah. Pasal 121 ayat (2) menyatakan "Sekretaris daerah sebagai mana dimaksud pada ayat (1) mempunyai tugas dan kewajiban membantu kepala daerah dalam menyusun kebijakan dan mengkoordinasikan dinasdinas daerah dan lembaga teknis lainnya".

Mengingat kewenangan Gubernur sebagai wakil pemerintah yang dimaksud Pasal 38 UU No. 32 tahun 2004 berdasarkan teori kewenangan berbentuk atribusi, hal itu membawa konsekuensi terhadap kewenangan gubernur. Dalam hubungan dengan itu gubernur dalam menjalankan tugas dan kewenangannya tidak dapat ditiadakan atau dihapus oleh peraturan perundang-undangan di bawahnya. Artinya dalam melakukan pembinaaan dan pengawasan terhadap kabupaten/kota di wilayahnya menjadi otoritas penuh gubernur. Tetapi kenyataannya dalam melakukan pembatasan Peraturan Daerah kabupaten/ kota kewenangan tersebut diambil alih oleh
Menteri Dalam Negeri, dengan demikian atribusi kewenangan gubernur telah dicabut. Dalam hal ini terlihat bahwa pemerintah tidak konsisten dengan kedudukan gubernus sebagai wakil pemerintah.

2. Gagasan Bentuk Kewenangan, Ruang Lingkupnya Serta Kelembagaan Gubernur Sebagai Wakil Pemerintah.

Sebagaimana di paparkan di atas bahwa kewenangan gubernur sebagai wakil pemerintah berhubungan dengan pelaksanaan asas dekonsentrasi.Asas dekonsentrasi merupakan asas dalam rangka pelaksanaan kewenangan pemerintah dalam bentuk pelimpahan wewenang pemerintahan oleh pemerintah kepada gubernur sebagai wakil pemerintah menurut Pasal 1 angka 8 UU No.32 tahun 2004. Karena bentuk negara Indonesia adalah negara kesatuan (unitary state) dengan sistem presidensial maka pemerintah berwenang sepenuhnya di wilayah negara,(Sri Soemantri, 1981:32) termasuk terhadap kabupaten /kota.

Prinsip negara kesatuan yang ditegaskan dalam Pasal 1 UUD 1945 memberikan kewenangan kepada presiden memegang kekuasaan pemerintah. Menurut sistem ini presidenlah yang memiliki kedudukan dan tanggung jawab tertinggi dalam penyelenggaraan pemerintah.Keberadaan organ-organ lain dalam penyelenggaraan pemerintahan seharusnya berdasarkan otoritas presiden, karena presidenlah yang memiliki atribusi kewenangan dalam menjalankan fungsi pemerintah (eksekutif).

Dalam era otonomi, terutama setelah perubahan UUD 1945 dengan menguatnya otonomi kabupaten/kota di khawatirkan hal itu mengganggu keutuhan NKRI.Untuk itulah kebijakan yang diambil memposisikan gubernur selain kepala daerah juga sebagai wakil pemerintah.Kedukan gubernur sebagai kepala pemerintahan daerah mempunyai dasar konstiotusional yang tegas serta memiliki tugas dan kewajiban yang tegas pula. Tetapi mengenai kedudukan gubernur sebagai wakil pemerintahan pengaturan kewenangannya masih menimbulkan berbagai perdebatan karena belum diatur secara tegas dan bahkan terdapat ketidak singkronan norma yang satu dengan yang lainnya. Hal tersebut terutama berkenaan dengan bentuk kewenangan, ruang lingkupnya maupun organ yang membantu gubernur menjalankan kewenangan sebagai 
wakil pemerintah.Untuk itulah diperlukan gagasan konsep yang jelas yang mencakup bentuk kewenangan, ruang lingkupnya dan organ yang membatu gubernur sebagai wakil pemerintah melaksanakan wewenang tersebut.

a. Bentuk kewenangan gubernur sebagai wakil pemerintah.

Di dalam UU No. 32/2004 terdapat berbagai jenis bentuk kewenangan gubernur sebagai wakil pemerintah terhadap kabupaten/kota.

Pertama, bentuk kewenangan berdasarkan Pasal 10 ayat (5) huruf b UU No. 32/2004 yang menyatakan "dalam melaksanakan urusan pemerintahan yang menjadi kewenangan pemerintah di luar urusan pemerintah sebagaimana dimaksud ayat (3) yakni kewenangan a. politik luar negeri, b. pertahanan, c. keamanan, d. yustisi, e. moneter dan fiscal nasional, dan agama, pemerintah dapat melimpahkan sebagian urusan pemerintahan kepada gubernur selaku wakil pemerintah". Ketentuan di atas mengamanatkan gubernur sebagai wakil pemerintah dapat memiliki kewenangan melalui pelimpahan (pendelegasian) kewenangan dari presiden.Dalam hal ini presiden harus membuat aturan yang berkenaan pendelegasian kewenangan kepada gubernur.Sumber kewenangan atau cara gubernur memperoleh kewenangan ini disebut dengan mandat.

Kedua, berdasarkan Pasal 38 UU No. 32 tahun 2004.Pasal tersebut menyebutkan secara tegas dan rinci tugas dan wewenang gubernur sebagai wakil pemerintah. Menurut Pasal 38 UU No. 32/2004 gubernur memperoleh kewenangan langsung dari pembentuk UU.Kewenangan yang di peroleh melalui UU artinya diberikan langsung legislator asli dikenal dengan atribusi.

Ketiga, berdasarkan Pasal 145 ayat (2) dan (3) mengenai pembatalan Peraturan Daerah dilakukan oleh pemerintah dengan Keputusan Presiden. Jika ketentuan tersebut dihubungkan dengan 37 ayat (3) PP No. 79 tahun 2005 tentang Pedoman Pembinaan dan Pengawasan Penyelenggaraan Pemerintahan Daerah, di mana menurut pasal tersebut pengawasan dilakukan oleh menteri (Menteri dalam Negeri), hal itu menunjukan pemerintah menarik kembali kewenangan pembinaan dan pengawasan kabupaten/kota dari kewenangan gubernur. Dalam bentuk kewenangan gubernur melalui cara ketiga ini karena tidak terjadi perpindakan kewenangan maka cara demikian disebut dengan mandat.

Dengan terdapatnya bentuk kewenangan gubernur terhadap kabupaten/kota seperti dipaparkan di atas, akan dapat menimbulkan keraguraguan gubernur dalam mengambil tindakan terhadap kabupaten/kota. Untuk itu, dengan memperhatikan bentuk negara dan sistem pemerintahan yang dianut, maka kewenangan gubernur sebagai wakil pemerintah diperoleh melalui delegasi. Dengan cara demikian pemerintah pusat tidak disibukan lagi oleh kabupaten kota, karena hal itu dapat ditangani oleh gubernur sebagai perpanjangan tangan pemerintah. Saat ini boleh dikatakan gubernur sebagai perpanjangan tangan pemerintah tidak efektif, kabupaten/kota dapat mem-by pass ke pusat untuk menyelesaikan persoalan yang dihadapinya.

b. Ruang lingkup kewenagan gubernur sebagai wakil pemerintah

Dalam sejarah pemerintahan di Indonesia bagaimanapun politik otonomi dijalankan, jabatan gubernur sebagai kepala pemerintahan provinsi selalu dijumbuhkan dengan wakil pemerintah (kepala wilayah).Namun suatu hal yang belum pernah diatur secara konsisten adalah ruang lingkup kewenangan gubernur tersebut. Karena kewenangan gubernur yang diatur dilakukan dalam rangkan melaksanakan asas dekonsentrasi, maka sudah semestinya ruang lingkup kewenangan gubernur tersebut tidak terbatas pada kewenangan yang diatur dalam Pasal 38 UU No. 32/2004, tetapi mencakup kewenangan yang berhubungan dengan penyelenggaraan urusan pemerintahan umum. Dalam bahasa Belanda urusan pemerintahan umum disebut dengan algemene bestuur, artinya urusan yang tidak dapat dilakukan oleh suatu instansi/ dinas khusus (J. Wajong, 1972:29).

Jika disimak perjalanan sejarah urusan pemerintahan umum yang menjadi kewenangan wakil pemerintah di daerah mencakup bidang-bidang: 
a. Mewakili kekuasaan dan menegakan wibawa pemerintah pusat;

b. Menjamin keamanan dan ketertiban umum;

c. Melakukan kebijaksanaan politik pemerintah pusat;

d. Menguasasi lingkungan daerah hukumnya dan kekayaan alam milik negara;

e. Memegang kendali atas penduduk;

f. Memelihara dan memajaukan kemakmuran dan kesejahteraan daerah (J. Wajong, 1972:29).

Di dalam UU No. 5/1974 kewenangan gubernur sebagai wakil pemerintah ruang lingkupnya mencakup urusan pemerintahan umum. Pengertian urusan pemerintahan umum dirumuskan dalam pasal 1 huruf j yakni mencakup "urusan yang meliputi bidang-bidang ketentraman dan ketertiban, politik, koordinasi, pengawasan dan urusan pemerintahan lainnya yang tidak termasuk dalam tugas sesuatu instansi dan tidak termasuk urusan rumah tangga daerah". Ruang lingkup wewenang, tugas dan kewajiban gubernur sebagai wakil pemerintah diatur dalam Pasal 81 UU No. 5/1974 jika dirinci wewenang, tugas dan kewajiban tersebut dapat dirinci sebagai berikut:

1. Dalam bidang polisionil menyangkut ketertiban dan ketentraman dalam masyarakat.

2. Dalam bidang politik dalam negeri baik menyangkut ideologi maupun keutuhan negara kesatuan

3. Dalam bidang koordinasi baik dalam bidang pemerintahan, pembangunan dan kemasyarakatan

4. Melakukan konseling dan supervise jalannya pemerintahan

5. Dalam bidang kekuasaan eksekutif pusat di daerah

6. Melaksanakan kewenangan residu ada yang menyebut dengan kewenangan bebas (vrije bestuur).

Ruang lingkup kewenangan gubernur sebagai wakil pemerintah menurut Pasal 38 UU No.32/2004 sagat limitatif karena hanya mencakup pembinaan dan pengawasan dan koordinasi terhadap kabupaten/kota yang limitatif. Sadar akan kelemahan Pasal 38 UU No. 32/2004 pemerintah mengeluarkan PP No. 19 Tahun 2010, kemudian diubah dengan PP No. 23 Tahun 2011. Ruang lingkup kewenangan gubernur sebagai wakil pemerintah menurut PP No. 19 Tahun 2010 Jo PP No. 23 Tahun 2011 pada dasarnya sama dengan ketentuan zaman penjajahan Belanda dan dengan yang diatur UU No. 451974.

Dengan memperhatikan ketentuanketentuan yang berlaku sejak penjajahan Belanda sampai saat ini, maka ruang lingkup kewenangan gubernur sebagai wakil pemerintahan haruslah mencakup kewenangan pemerintahan umum.

c. Organ Pelaksana Kewenangan Gubernus Sebagai Wakil Pemerintah

Untuk menjalankan suatu kewenangan diperlukan suatu organ pemerintahan.Sehubungan dengan organ pemerintahan Hans Kelsen sebagaimana dikutip oleh Jimly Asshiddiqie memberikan pengertian yakni siapa saja yang menjalankan suatu fungsi yang ditentukan oleh suatu tata hukum (legal orde) (Jimly Asshiddiqie, 2010:31). Mereka yang menjalankan fungsi pemerintahan tersebut memiliki kewenangan berdasarkan hukum publik.Organ yang memiliki kewenangan pemerintahan dalam kepustakaan Belanda disebut dengan jabatan (ambt), sedangkan pemangku jabatan disebut dengan ambtdrager Sejalan dengan prinsip akuntabilitas organ atau badan yang mengemban kewenangan harus bertanggung jawab terhadap keberhasilan pelaksanaan kewenangan tersebut.Demikian juga dengan kewenangan pemerintahan pusat dijalankan oleh gubernur di wilayahnya yang harus dipertanggung jawabkan baik secara jabatan maupun secara hokum.

UU No. 32 tahun 2004 telah memberikan atribusi kewenangan kepada gubernur sebagai wakil pemerintah.Masalahnya adalah organ mana/apa yang membantu gubernur dalam menjalankan tugas dan wewenang tersebut. Dalam UU No. 32/2004 tidak diatur organ yang akan menjalankan tugas pemerintahan pusat di provinsi, hal itu berbeda dengan yang pernah diatur dalam UU No. 5/1974, karena ketika itu 
sekretariat daerah sekaligus sekretariat gubernur sebagai wakil pemerintah sebutan pimpinannya dengan sekretaris wilayah daerah (sekwilda).

Sehubungan dengan organ pelaksana kewenangan gubernur sebagai wakil pemerintah Andy Ramses M dan La Bakry menyatakan penyelenggaraan tugas dan wewenang gubernur selaku wakil pemerintah hanya dapat efektif jika didukung pengorganisasi relevan (Andi Ramses dan La Bakry, 2008:91). Saat ini pelaksanaan kewenangan gubernur sebagai wakil pemerintah dilaksanakan bukan oleh organ pusat tetapi oleh Satuan Kerja Perangkat Daerah (SKPD).Karena hakekatnya kewenangan gubernur sebagai wakil pemerintah berkenaan pengawasan dan pembinaan terhadap kabupaten/kota yang nota bene adalah daerah otonom. Karenanya pengawasan daerah otonomi oleh organ otonomi lainnya menimbulkan kesan otonomi hirarki atau bertingkat sehingga otonomi dapat diintervensi oleg daerah otonomi lainnya yang lebih tinggi. Jadi tidaktepat tugas dan wewenang gubernur sebagai wakil pemerintah dalam melakukan pengawasan dan pembinaan kabupaten/kota dilakukan oleh SKPD Provinsi sebagaimana terjadi saat ini.

Untuk mengatasi persoalan mengenai pengorganisasi yang akan melaksanakan tugas dan wewenang gubernur tersebut di dalam PP No. 19 /2010 jo PP No. 23/2011, di buka peluang pembentukan organisasi pelaksana tugas dan wewenang Gubernur sebagai wakil pemerintah. Peluang tersebut diatur dalam Pasal 17 PP No.19/2010 jo No.23/2011 menyatakan “

1. Dalam melaksanakan tugas dan wewenang sebagaiman dimaksud dalam Pasal 3 dan Pasal 4, gubernur dibantu oleh sekretaris gubernur.

2. Sekretaris gubernur sebagaimana dimaksud pada ayat (1) secara ex officio dijabat oleh sekretaris daerah provinsi.

3. Sekretaris gubernur sebagaimana dimaksud pada ayat (2) secara operasional dibantu oleh kelompok jabatan fungsional.
Jika ketentuan di atas dianalis secara mendalam terlihat kegamangan atau bahkan kebingungan pemerintah dalam mengatasi organ yang melaksanakan tugas dan wewenang gubernur sebagai wakil pemerintah. Dikatakan demikiankarena Pasal 17 PP tersebut tidak sinkron bahkan bertentangan dengan Pasal 120 ayat (1) UU No. 32 tahun 2004 yang tegas mengatakan " Perangkat daerah provinsi terdiri atas sekretariat daerah, sekretariat DPRD, dinas daerah dan lembaga teknis daerah. Selanjutnya dalam Pasal 121 ayat (1) dinyatakan "Sekretariat daerah dipimpin oleh seorang sekretaris daerah. Pasal 121 ayat (2) menyatakan "Sekretaris daerah sebagai mana dimaksud pada ayat (1) mempunyai tugas dan kewajiban membantu kepala daerah dalam menyusun kebijakan dan mengkoordinasikan dinas-dinas daerah dan lembaga teknis lainnya".

Dengan gaambaran di atas berdasarkan Pasal 120 ayat (1) dan Pasal 121 ayat (1) dan (2) tegas menyatakan kedudukan sekretaris daerah adalah organ daerah. Kemudian dengan Pasal 17 PP No. 23 /2011 begitu saja merubah yang telah tegas diatur oleh UU, sehingga terdapat pertentang norma yang lebih rendah terhadap norma yang lebih tinggi. Kondisi ini bertentang stufentheorie yang merupakan grandtheory dalam pembentukan norma hukum negara.

Kebingungan dan kegamangan pemerintah selanjutnya terlihat dari ketentuan Pasal 17 ayat (3) PP no/19/2010 yang menyatakan "sekretaris gubernur dibantu oleh sekretariat dan tenaga ahli". Kemudan ketentuan tersebut oleh PP no. 23/2011 rumusan pasal tersebut dirubah menjadi " sekretaris gubernur cara operasional dibantu oleh kelompok jabatan fungsional". Ketentuan tersebut sangat naïf, karena seorang pejabat di provinsi akan memimpin dua sekretariat sekaligus yakni sekretariat daerah provinsi dan sekretariat gubenur. Sadar akan hal itu pemerintah akhirnya dengan PP No. 23/2011 menghilangkan kelembaagaan secretariat gubernur.

Selanjutnya ketika pemerintah Dalam Pasal 17 ayat (3) PP No. 19/2010 juga mengatur tenaga ahli kondisinya menjadi lebih rancu, karena dalam PP 
No.41 Tahun 2007 tentang Organisasi Perangkat Daerah (PP No.41/2007) juga mengatur tenaga ahli pemerintahan daerah. Jadi seorang gubernur akan di kelilingi 2 (dua) kelompok tenaga ahli dengan pola ini akan menimbulkan tabrakan kewenangan. Sekalipun ketentuan Pasal 17 PP No.19/2010 dirubah redaksinya oleh PP No.23/2011 menjadi kelompok jabatan fungsional, tetapi pada prinsipnya jabatan fungsional adalah jabatan keahlian yang dikenal dalam hokum kepegawaian.

Untuk mengatasi kebingungan pemerintah mengenai organ yang akan melaksanakan tugas dan wewenang gubernur sebagai wakil pemerintah, diperlukan aturan yang tegas mengenai organ yang akan membantu gubernur sebagai wakil pemerintah, di mana organ tersebut terpisah dari organ daerah karena kewenangan yang akan dijalankannya juga berbeda. Pengaturan organ daerah sekaligus menjadi organ pusat harus dinyatakan secara tegas dalam UU, tidak boleh PP membuat norma sendiri yang bertenyangan dengan UU.

\section{B. Kesimpulan dan Saran}

\section{Kesimpulan}

a. Pengaturan kewenangan gubernur sebagai wakil pemerintah di dalam UU No. 32/2004 adalah dalam rangka pelaksanaan asas dekonsentrasi. Sedangkan UUD 1945 sebagai dasar pembentukan UU No.32/2004 tidak mengatur asas dekonsentrasi, hal itu sangat berbeda dengan dedudukan gubernur sebagai kepala pemerintahan daerah di dalam UUD 1945 tegas diatur asas otonomi. Oleh karena itu pengaturan kewenangan gubernur sebagai wakil pemerintah tidak dapat dicarikan valisasinya dalam UU 1945.

b. UU No. 32/2004 dan ketentuan pelaksanaannya tidak tegas mengatur bentuk kewenangan gubernur sebagai wakil pemerintah, karena satu sisi kewenangan gubernur berupa atribusi sebagaimana dimaksud pasal 38 , sisi lain berupa mandate sebagaimana dimaksud pasal 10 ayat (5) huruf b, dan pada bagian lain dalam PP No. 79/2005 serta dalam kenyataannya kewenangan tersebut berupa mandat.

\section{Saran}

a. Badan yang berwenang membentu UUD perlu mengatur secara tegas dilaksanakannya asas dekonsentrasi sebagaimana halnya dengan asas otonomi dan tugas pembantuan.

b. Badan pembentuk UU dalam mengatur kewenangan gubernur sebagai wakil pemerintah harus menyesuaikan dengan bentuk negara kesatuan. Karena itu bentuk kewenangan gubernur berupa delegasi. Sedangkan mengenai ruang lingkup kewenangan gubernur terse dan presidenlah yang melimpahkan kewenangan kepada gubernur sebagai wakil pemerintahut jangan hanya terbatas pada pembinaan, pengawasan dan koordinasi terhadap kabupaten/kota saja tetapi harus mencakup kewenangan pemerintahan umum. Serta kewenangan tersebut harus tegas organ yang menjalankannya adalah organ pusat bukan ditugaskan kepada SKPD. 


\section{dAFTAR PUSTAKA}

Andi Ramses dan La Bakry, 2008, Pengaturan Kedudukan Gubernur Sebagai Wakil Pemerintah di Daerah, dalam Jurnal IImu pemerintahan, Edisi 26, Penerbit MIPI.

Agussalim Andi Gadjong, 2007, pemerintahan daerah, kajian politik dan hukum, Ghalia Indonesia, Jakarta. Bagir Manan, 2004, Menyongsong fajar otonomi daerah, Cetak 4. PSH Fak.Hukum UII, Yogyakarta.

F. Sugeng Istanto, 2007, penelitian Hukum, Cv.Ganda, Yogjakarta.

HR Ridwan, 2006, Hukum Administrasi Negara, UII Press, Yogjakarta.

Indroharto, 1990, Usaha memahami Undang-Undang tentang perdilan TataUsaha Negara, Sinar Harapan, Jakarta.

Jimly Asshiddiqqie, 2002, Konsolidasi UUD 1945 pasca Perubahan Keempat, PSHTN-UI, Jakarta.

Jimly Asshiddiqqie, 2010, Perkembanmgan dan konsolidasi lembaga Negara, Pasca reformasi, Sianr Grafika, Jakarta.

Jimly Asshiddiqie dan Ali Safaat, 2012, Teori Hans Kelsen, tentang Hukum, cetak kedua, Konstitusi Press, Jakarta.

J. Wajong, 1972, Kedudukan dan tugas pamong praja, Cetak Kedua, Ichtiar, Jakarta.

Lukman Hakim, 2012, Filosofis Kewenangan Organ Lembaga Daerah, Setara Press, Malang.

Peter Mahmud Marzuki, 2007, penelitian Hukum, Cetakan ke 3, Prenada Media Group, Jakarta.

Saldi Isra, pergeseran Fungsi Legislasi dalam sistem pemerintahan Indonesia setelahperubahan UndangUndang dasar 1945, Ringkasan Desertasi, Jogjakarta.

Philipus M. Hajon, 1993, pemerintahan Menurut Hukum (Wet-en Rechtmatig Bestuur), Yuridika, Surabaya, Edisi Agustus.

Sri Soemantri, 1981, pengantar perbandingan Antar Hukum Tata Negara, Rajawali, Jakarta.

Wijk-Konijnenbelt, 1991, Hoofdstukken van Administratief recht, virga Uitgeverij BvS, Gravenhagen, Utrecht. 